Article

\title{
Gender and (Un)Sustainability-Can Communication Solve a Conflict of Norms?
}

\section{Angela Franz-Balsen}

Avenue de Tervueren 266 C, 1150 Brussels, Belgium; E-Mail: franzbal@leuphana.de; Tel.: +32-47313-7026; Fax: +32-2-64822-45

Received: 2 January 2014; in revised form: 31 March 2014 / Accepted: 1 April 2014 / Published: 10 April 2014

\begin{abstract}
In theory, and even more in the practice of sustainability communications, the gender dimension of sustainability has been neglected relative to other fields of the science. The aim of this paper is to show the relevance of gender as an analytical category for research and the importance of gender competence as an indispensable skill for professional sustainability communicators. Understanding how gender norms have contributed to inhibiting sustainable development is key to well-targeted means to communicate visions of sustainable ways of life. Traditional norms of masculinity are clearly in tension with the ethical, ecological and social implications of Sustainable Development, whereas the norms of femininity work against empowerment and participation of women. Current changes in gender relations and gender identities in the western world do not automatically solve this conflict of norms. Therefore, sustainability communication must and can contribute to shaping the social construction of gender towards new "sustainable" norms and ideals for the various gender identities in western societies. In order to achieve this, gender mainstreaming (GM) needs to be implemented in the field of sustainability communication, from capacity building for communicators to project design and research. Gender and diversity competence is to become a professional requirement, assuring that traditional "doing gender" is avoided, cultural diversity respected and structural inequalities are made visible. Visions of sustainable societies should include changes in gender relations. The argument is based on sociological studies, gender theories, gender policies, and environmental and sustainability communication studies, empirically supported by biographical studies and media analyses over the last twenty years in Western Europe, mainly Germany.
\end{abstract}


Keywords: gender; masculinity; femininity; unsustainability; sustainability communication; gender mainstreaming; gender competence; gender and diversity

\section{Introduction}

Sustainability communication aims at promoting the process of sustainable development by addressing target groups - be it organizations, groups or individuals - in order to raise awareness for and knowledge of current and future concerns. It offers visions of sustainability, spreads the news of innovative solutions for socio-ecological problems and tries to involve, encourage and empower people to solve their own problems and those of their communities. This touches upon issues of social and environmental responsibility and thus of social norms and values.

Norms and values - people's belief systems and convictions - are quite often gendered in regard to environmental issues [1-3]. This paper presents the argument that the social construction of gender is a crucial factor that sustainability communication has to take into account when it wants to inform and persuade various target groups. The results of gender research have a lot to offer for a better understanding of reality, for example why the persisting unsustainability of the civilized world is so hard to change, whether at the local level or in world politics [4].

First of all, however, it is necessary that researchers, lecturers and practitioners learn to see, which means to discover, the old and new mechanisms of the social construction of gender. They have to acquire gender competence. Gender competence consists of gender expertise (awareness of the social construction of gender and understanding the complexity of gender relations) in combination with methodical skills for application in professional contexts. Gender training, as part of a larger gender mainstreaming effort, is often the first step towards gender competence. Gender mainstreaming was implemented at the end of 1990s as a top-down political instrument against inequalities and discrimination in everyday life. It has also been applied to fight gender blindness in research and to establish research cultures that will profit from an overall gender strategy. In an overall gender strategy, the framing of research projects is of importance, too. The researcher's gender assumptions and beliefs are as important as the research subjects' and users' gender needs, assumptions, and behaviors.

Looking at the limited number of publications on the interface of gender and sustainability communication, it is more than a guess to say that the integration of gender into theory and practice of sustainability communication is poor. Following is an assessment of the state of the art.

\subsection{Gender in Sustainability Communication-State of Art}

Confusion about possible relations between gender and sustainability and ignorance about a shift of paradigm that took place in the 1990s in gender research have delayed the integration of current standards of gender mainstreaming in all fields of professional sustainability communications, from (Higher) Education for Sustainable Development (HESD, ESD) to social marketing, from public relations to sustainability journalism. The bias that gender is just a women's issue still prevails. This is fostered by a multitude of publications that promise to give a comprehensive overview of "gender and sustainability", but fall short of this aim by focusing only on one of the many possible features of this 
relationship: women - that is to say women as a demographically defined part of populations - and gender equality, e.g., [5,6].

As an example from sustainability communication let's have a closer look at "The Bonn Declaration", the final document of the UNESCO World Conference on Education for Sustainable Development, setting the course for ESD worldwide [7]. Gender equality is mentioned in all parts of the document, for example "Gender equality, with special reference to the participation of women and girl children in education, is critical for enabling development and sustainability" (paragraph 5). In the call for action, it says, "ESD should actively promote gender equality, as well as create conditions and strategies that enable women to share knowledge and experience of bringing about social change and human well-being" (paragraph $15 \mathrm{~m}$ ). Such repeated and prominently placed attention to the gender issue in ESD is a great progress. On the other hand, a very traditional understanding of gender shines through: gender is reduced to gender equality with focus on women and girls only. Furthermore, the popular myth of women as actors who have "the experience of bringing about social change and human well-being" is applied, thus attributing responsibility to women instead of looking for systemic solutions. Some authors call this a "feminization of environmental responsibility" [8,9].

If we look at campaigning and social marketing for the environment, this feminization of environmental responsibility was typical of the early years. In the early 1990s, for instance, the German Ministry of the Environment broadcasted a series of spots in which a female comic figure teaches a stupid man to recycle in the correct way. The notion of the caring woman is the leading motive of the spots, as was confirmed by the ministry. Women would be reassured in their stereotype role, while men would not be pleased with their representation and probably not be motivated by the spot to act more environmentally friendly. Twenty years later one finds campaigns that depict men and women happily sharing the recycling job [10]. A comprehensive European study by Schultz/Stiess on gender aspects in sustainable consumption (SC) patterns claims that a moralization of women's responsibility can still be observed and recommends a new focus: agency of women and men (their societal limits to contribute to sustainable development) [9] (p. 2). The concept of the political consumer or the consumer-citizen is elaborated or gendered by the authors' proposal of the term "gender responsiveness to SC instruments". For example: women pay more attention to product labels, men react to technological innovations, efficiency, etc. So progress has been made, but the challenge of awareness of stereotypes also remains in this new concept.

Handbooks of Sustainability Communications do not expand very much on gender-sensitive approaches, even though they recommend as key principle: Know your audience! In UNEP-Futerra 2005, there is one reference to gender as a factor in assessing target groups, but it is mainly gender-neutral [11]. In a German handbook on sustainability communication, which recommends addressing target groups according to their lifestyles, special features of men and women are at least mentioned [12]. However, as long as women are only addressed in their role as housewives this kind of gender-sensitive approach reconstructs the old stereotype.

When the context is developmental as in "Environmental Education and Communication for a Sustainable World. A Handbook for International Practitioners", we find a chapter titled "Gender matters" as early as in 2000 [13] (pp. 23-31), which gives detailed explanation of tools of gender analysis. This has to do with the fact that gender mainstreaming was developed and implemented in international development. Environmental communication beyond the developmental context, 
however, is still far from practicing gender mainstreaming, and it is one of the aims of this paper to illustrate what the advantages of it could be.

\subsection{Gender in Sustainability Communication Research}

In his survey on environmental communication research over the past four decades, Hansen made no special reference to gender aspects [14]. The survey focuses on the media aspects of environmental communication, analyzing research on the journalistic production, content and social implications of environmental communication.

Some studies do consider the gender dimension, perhaps due to the close relationship between social psychology and cultural studies where gender media studies are a tradition. Gender analysis in sustainability communication is found in the following forms:

(a) Content analysis of media like posters, films, clips, and advertisements, is often assigned in seminars. The traditions of gender studies and gender media studies are used to analyze such media products. An outstanding study was done by Rogers in which he analyzed three advertisements and worked out the complex interrelations between meat consumption as a code for masculinity, sustainability as a threat to hegemonic masculinity, and masculinity as a threat to sustainability [15]. See also Section 3.1.

(b) Studies on women/men as target groups exploring differences in environmental awareness [16,17] or behavior.

Aside from the few exceptions mentioned, it can be supposed that the wealth of theory and tools of gender research have yet to be properly employed in sustainability communication research. A study like the one by Rogers [15] shows there is much more to find out than counting numbers of males/females or measuring differences in attitudes and behavior. Media analyses offer wonderful material for academic courses to make the abstract (invisible) concepts of gender and sustainability visible and understandable to students [18]. However, at most universities sustainability studies and gender studies are separate or "parallel worlds", with only a few engaged individual researchers/lecturers bridging the gap.

\section{Methodical Approach}

\subsection{Empirical Data Base}

This article sums up a research process carried out over the last 20 years mainly at the German Institute of Adult Education (DIE, Bonn) and at the Institute of Environmental and Sustainability Communication (INFU), Leuphana University Lueneburg. The empirical data base of the argument are:

(I) A random but comprehensive collection of examples (archive) of public communication focusing on.

(a) Public discourse on gender issues in times of cultural change (top stories in leading journals, tv-programms, tv-spots)

(b) Social marketing campaigns for environmental protection/sustainable development. 
Content-analysis from a gender-perspective of these materials was done first by the author and then discussed in lectures, seminars and workshops with participants, often in a comparative, diachronic perspective from 1980s to 2013.

(II) A biographical study of German pioneers in environmental communication [19], using 20 extensive narrative interviews [20,21] collected between 1998 and 2002; The aim of this research was to analyse about the establishment of environmental communication as a newly emerging branch of environmental careers and about potential issues of social construction of gender in the process of professionalisation. The same number of male and female interviewees were gradually selected from the diverse areas of the field (journalism, film, public relations, corporate communications, community services, education); the interviews were made in form of uninterrupted narrations, with only a few claryfying questions at the end; following the method of Grounded Theory [22], the approach to the qualitative data had to be very open in the beginning (open coding), then was narrowed down to research questions (theoretical sensitive coding) that emerged from the data; the validation of preliminary results was achieved in interpretation workshops at different universities.

\subsection{Theoretical and Historical Background}

The scope of this article calls for a theoretical frame that ranges from theoretical models of norms and values, sustainability studies to gender studies and gender policies (Gender Mainstreaming) up to media studies and environmental communication research. To give a review of all these fields is beyond the limits of this contribution. In order to underpin the theses of this paper, however, a short introduction into major developments in gender research and into the methodology of gender analysis seems indispensable.

\subsubsection{Gender Research before and after 2000}

The origins of gender research lay in the feminist movement as well as in the feminist critique of science [23-25]. In the 1970s and 1980s, more gender equality in society and the introduction of female perspectives into an androcentric scientific system was the political aim of this research. Feminist studies turned into women's studies when the relevance of this research became gradually acknowledged and a distinction was made between academic and political spheres. Women remained the core research objects, however, until men's studies came up as an analogy [26,27], accompanied by queer studies. Based on the theses of the social construction of gender [28] the gender discourse shifted from the dualism of women vs. men to concepts of masculinity and femininity as well as diverse sexual identities, a level of abstraction that allowed for a certain distance to the objects of research which had been missing before. Nevertheless, it took a long time before it was generally understood that gender research is no longer confined to women's issues. Today, research is confronted with a diversity of gender identities in addition to the other characteristics of individuals or groups (ethnicity, age, religion). Looking back, different forms or stages of gender studies (here used as an umbrella term) can be discerned, characterized by their research subjects and their respective ideological or academic approaches: 
In the context of environmental and sustainability research, the term "ecofeminism" has sometimes been falsely used to represent any gender perspective on environmental issues. Such a simplification ignores the very special history and the multitude of streams of ecofeminism, ranging from women's projects in countries of the global South which were typical of the early years of ecofeminism to a number of very distinct academic, often philosophical discourses from 1990 onwards on various continents [29-32]. According to Katz [33] there is no coherent theory of ecofeminism and any effort to systematize the diversity of approaches is doomed to fail. A common denominator, however, could be the vision of social equality in societies and ecologically intact environments [33] (p. 106). A current research focus is on alternative concepts of economy [34,35]. A fusion of feminist and ecological economic theory is presented by Biesecker and Hofmeister who invented the category "(re)productivity" in order to show the "complex interplay, and interdependence, of productive processes in social and ecological space" [35] (p. 1707). It is conceived as a category of mediation, bridging the gap between the reproductive and the productive, between nature and society.

Ecofeminism was seldom acknowledged in mainstream gender research. And it took about 20 years until so-called gender and environment research made its way into sustainability sciences [10]. Today the gender dimension has become a requisite of socio-ecological research in Europe.

Table 1. Development of gender studies from 1970s to 2010.

\begin{tabular}{|c|c|c|}
\hline Research object & Name of research & Approach \\
\hline Women $v s$. patriarchalism & $\begin{array}{l}\text { Feminist studies } \\
1970 \text { and } 1980 \mathrm{~s}\end{array}$ & $\begin{array}{l}\text { advocacy in research, } \\
\text { women friendly }\end{array}$ \\
\hline Scientific system & $\begin{array}{l}\text { Feminist critique of } \\
\text { science } 1970 \text { and } 1980 \mathrm{~s}\end{array}$ & epistemological \\
\hline Women/femininity & $\begin{array}{l}\text { Women's studies } \\
\text { 1980s onwards }\end{array}$ & $\begin{array}{l}\text { Academically integrated, } \\
\text { less political than feminist } \\
\text { studies }\end{array}$ \\
\hline Women/nature/environment & $\begin{array}{l}\text { Ecofeminism } \\
\text { 1980s onwards }\end{array}$ & $\begin{array}{l}\text { Starting from social } \\
\text { movements, turning into } \\
\text { academic research }\end{array}$ \\
\hline Masculinity/masculinities & $\begin{array}{l}\text { Men's studies } \\
\text { Starting around } 1986\end{array}$ & $\begin{array}{l}\text { Analogy to women's } \\
\text { studies, partly advocatory }\end{array}$ \\
\hline $\begin{array}{l}\text { Femininity/masculinity and } \\
\text { gender relations }\end{array}$ & $\begin{array}{l}\text { Gender studies } \\
\text { Starting around } 1990\end{array}$ & $\begin{array}{l}\text { gender-sensitive in a broad } \\
\text { sense }\end{array}$ \\
\hline diverse sexual identities & $\begin{array}{l}\text { Queer studies } \\
\text { Starting in early 1990s }\end{array}$ & $\begin{array}{l}\text { Gender-sensitive in a broad } \\
\text { sense, advocatory for gay } \\
\text { movement, transgender etc. }\end{array}$ \\
\hline $\begin{array}{l}\text { Complex interplay of gender, } \\
\text { ethnicity, class, age, religion, } \\
\text { abilities etc. }\end{array}$ & $\begin{array}{l}\text { Gender and Diversity } \\
\text { or Intersectionality } \\
\text { Starting around } 2005\end{array}$ & $\begin{array}{l}\text { Gender only one of several } \\
\text { categories of analysis; } \\
\text { anti-discriminatory aspects }\end{array}$ \\
\hline
\end{tabular}

Of the major developments listed in Table 1, the most important for sustainability communication professionals is gender and diversity if they want to meet today's standards of political correctness. In the first decade of the new millennium, the gender and diversity concept, at first applied in companies and organisations, was used to integrate gender into a complex array of characteristics that influence 
the position of individuals in society in keeping with the US-related concept of intersectionality [36]. These refer to parallel aspects of identity (race, gender, class, religion, sexual orientation, abilities) and how they interact and affect equality, with an anti-discriminatory background.

For environmental communication researchers, it is essential to know that today we have a variety of parallel approaches, often subsumed under the umbrella term "gender studies". The findings of such studies can be useful for the interpretation of communication processes and products.

This brings us to the question of how the social construction of gender can be systematically analyzed. Manifestations of gender can be analyzed at three levels [24,37]:

- The abstract level of symbols, norms, myths of masculinity vs. feminity;

- The concrete level of societal (infra)structures that help organize our daily life (family, education, work, health, transport) and prestructure individual behavior;

- The concrete level of individuals' lifes (biographies).

The norms and myths associated with the dualism of traditional male/female roles and connotations are attributed to individuals or groups on the concrete levels of societal structures and individual practices. This is called "doing gender". Media and advertising, education and organizational culture in the workplace play an import role in this process of social construction of gender. They can either contribute to confirming traditional gender norms (dualism male/female; stereotypes of masculinity/femininity) or to changing and adapting the latter to deal with the changes and challenges societies have been facing at the beginnings of the 21 st century.

The joint EU-University of Stanford project "Gendered Innovation" offers exhaustive information materials that are recommended for use when a pragmatic introduction to sex and gender analysis is needed [38]. It should be noted that the overview given above is reductionist and pragmatic, leaving aside many ideological, philosophical and epistemological debates. It was intended to provide basic terminology and concepts used in formulating the following theses on Gender and Unsustainability.

\section{Results: Gender and Unsustainability}

Reviewing literature on possible relations between gender and sustainable development the majority of studies is of limited scope and unbalanced insofar as the term gender is used to talk exclusively about women as a demographic part of populations or about femininity as a path towards sustainability, e.g., [5]. Without questioning that social equity, environmental justice and participation of women are key issues of sustainable development, it can be criticized that the other half of humankind and their role regarding sustainable development has been entirely neglected. "The literature fails to highlight the fact that environmental change also affects men, though differentially. Future studies should shift from a focus on women to a true gender approach" [39] (p. 10). The heritage of feminist and ecofeminist studies may be an explanation for this selective approach to gender issues, which in the end reconfirms the criticized dualism women $v s$. men and the feminization of environmental responsibility. Here the effort is made to rethink possible relations between the social construction of gender and sustainability, using gender theory with a focus on masculinities, research on gender and environment/sustainability as well as findings from social psychology, environmental communication research and sociology in general. Some questions, left open so far in environmental 
psychology (e.g., the search for explanations of reproducible gender/race effects in studies on risk perception [3,4,40-42], might find an answer in this interdisciplinary synthesis of research. And it will show that gender-analized at the level of norms, symbols and myths and following their impact on societal structures and individual lives-has much more to do with unsustainability than with sustainability. A conflict of norms exists between traditional norms of masculinity and femininity and the norms inherent to the concept of sustainable development. Individuals may perceive this conflict as a dilemma, e.g. in household decisions, in the education of children, as citizens or at work.

\subsection{Masculinity and Unsustainability}

Pro-environmental attitudes and behaviors as well as engagement for a sustainable future are linked to people's norms and values [2,43]. There is also a great deal of empirical evidence of a gender factor in environmental awareness and behavior and in civil engagement [44-47]. Therefore it seems logical to have a closer look at norms and values in the standard western gender system, which on the abstract level (compare Section 2.2.1) consists of not more than two norms: the traditional norms of masculinity and femininity. .Alternative models are emerging, like Samuel Lurie's "authentic gender model" [48], an alternative to the dualistic gender model that is able to cover the variety of gender identities that exist, but they are far from being known to a broad public. Therefore it seems legitimate to describe the impact of the traditional gender model on societal structures and on individuals, even on those whose identity is in extreme conflict with the culturally prescribed gender roles.

The valid norms of masculinity in western civilization evoke the image of a strong, tough personality, a working man, integrated into the labour market, who is able to support a family which he ideally is part of [49]. Heterosexuality is an integral part of this norm (heteronormativity). This ideal masculine figure is competitive in the sense that he tries to be better than others. In short: he is a winner, not a loser, which means that subordination of others (women, homosexual men or less successful men) is implicit in this concept of masculinity. It was identified as a strategy to stabilize the system of male dominance in society by Robert (Raewynn) Connell, an Australian pioneer in men's studies, who called it "hegemonic masculinity" [27]. Connell included in his model of hegemonic masculinity the feature "white man" which stands for a superior position compared to members of non-white ethnicities. In the mid-nineties, when this theory was developed, a non-white president of the US was beyond imagination, but Connell might still be right: The so-called white-man-effect has been described in several socio-psychological studies. Flynn, Slovic and Mertz were the first to reveal that risk perception differs not only between men and women in the US, but also between the group of white men and people of colour [40]. To further explore the links between race, gender and environmentalism a number of more detailed studies examined differences in values and pro-environmental beliefs $[4,41]$, confirming more clearly that white males perceive the risks of health and technology hazards disproportionately as low compared to white females and people of colour. Sociopolitical factors such as worldviews (trust in institutions and authorities) are the explanations generated so far. "These results suggest that the attitudes of White men in the US are anomalous, perhaps because of their historically privileged position regarding risk and power in society" [3] (p. 112). As Palmer found out, more research is needed comparing ethnicities in the US and worldwide [42], but the WHM (White Heterosexual Male) has become a standard figure also in cultural debates [50]. 
What exactly is the conflict between hegemonic masculinity and the norms and values inherent in the concept of sustainability? It is basically the idea of intra- and intergenerational justice that does not go together with striving for short-term success - the financial crisis and climate politics are examples of this incompatibility. $\mathrm{CO}_{2}$-emissions are not considered a risk as long as they promise economic growth and immediate profit, as the backlash in climate talks shows (2009 Copenhagen; 2013 Warsaw); uncontrolled exploitation of resources (materials and human resources) is necessary to compete in the market. Competitiveness is the overall manifestation of hegemonic masculinity that entails the ongoing unsustainability of the globalized economic system. Responsibility here means to guarantee the stabilization and continuation of the privileged situation associated with hegemonic masculinities, based on the subordination and marginalization of other groups. Mellor describes the same phenomenon using the term "economic man" "Economic man is not young or old, sick or unhappy and does not have pressing domestic demands that cannot be ignored or put off" [31] (p. 158). Likewise, the sociologist Castells finds that patriarchalism depends on a traditional family model [49]. Sustainable development challenges or even threatens this privileged position. If one looks at the ethics and values of Sustainable Development, as they have been operationalized in the Earth Charter [51], this becomes very clear:

(I) Respect and care for the community of life (e.g., long-term thinking; respect of human rights);

(II) Ecological integrity (e.g., by a precautionary approach);

(III) Social and economic justice (equitable distribution of wealth within nations and among nations; elimination of discrimination in all its forms);

(IV)Democracy, nonviolence and peace (e.g., participation in decision-making).

If sustainability is a threat to masculinity, just as the empowerment of women and other groups was and still is, then masculinity has to be defended. Connell talks of "fragile masculinities" that constantly have to be reestablished, and the crisis of masculinity has filled the feuilleton pages of leading journals in Europe [52] and United States. Advertisements for symbols of masculinity like watches or cars use slogans like "Be a real man!" In a controversial series of advertisements of the International Watch Company (IWC) it says in small print, that the Swiss watches have been made since 1866 and will be made "as long as there are men" [53]. Since the campaign included sexist comments about women (gender harassment), it was finally stopped due to public protest [54]. In a brilliant analysis of three television advertisements Rogers shows how anti-feminist, anti-vegetarian and anti-environmental messages around meat consumption are used to restore hegemonic masculinity: "In these commercials the eating of beef is not simply coded as a masculine activity; it [...] is specifically coded as a means of restoring hegemonic masculinity in the face of threats to its continued dominance. By understanding these advertisements as a response to a perceived crisis in masculinity and by paying attention to the role of intersectionality (the interplay of multiple lines of domination), new insights can be achieved concerning the contemporary state of masculinity, the "crisis" therein, and the role of environmental and animal rights movements in constituting the crisis" [15] (p. 282).

It is important to note that when hegemonic masculinity is described, we are not talking about individual men or the male part of populations, but about an idealization of masculinity. The social construct of hegemonic masculinity affects men most by the expectations they have to meet, but it is not tied to a male body: women may internalize the masculine norm of competitiveness and dominance just as well, because it is key for success in the workplace or in politics. In addition, as mothers 
educating a son to become a real boy/man, or as teachers, women may use the symbols and myths around hegemonic masculinity, thus "doing gender".

\section{2. "Not Better, but Different"-Femininity and Unsustainability}

In Europe and the US, femininity is associated with two normative social constructions of gender: the good mother and the beautiful woman, and both put a lot of pressure on modern women. The good mother as symbol of femininity is not an archetype, as one might think, but was culturally constructed in Europe's upper class in the 18th century, as Elizabeth Badinter explained in her controversial book "Mutterliebe" [55]. Today the idealistic model of selfless mother love with its essentialist traits is demystified in academic and public discourses, and fathering is becoming a common practice. However, as a social norm it is still very powerful, reaffirmed by new waves of mothering among young women, accompanied by the phenomenon of modern (working) mothers' guilt [56]. The pressure goes even further: Women without children often feel less esteemed than mothers in their environment.

The second norm of femininity is that of the beautiful woman. According to Degele, it is the counterpart of hegemonic masculinity, insofar as physical attractiveness is used as a means of social distinction, as a "hegemonic norm" [57]. A beautiful woman exerts a certain power on men and is socially more accepted and esteemed than less beautiful females. What is considered beautiful at a certain place and time in history is culturally constructed, today mainly by mass media. In 21 st century Europe or North America, a woman is considered physically attractive when she is slim, tall and looking young. Unfortunately, only a small percentage of the female population is slim and tall with young looks. Anorexia and excessive use of Botox are expressions of the stress young and old females have in order to meet the social norms of physical attractiveness. "Beautification", a term formerly used for urban environments, can now be applied to human bodies.

What has all this to do with (un)sustainability? To sum up: The social expectations that women have to meet in their gender roles do not encourage them to look beyond the family or local microcosm: responsibility is attributed to women for the well-being of members of family (unpaid reproductive labor) and for the styling of their bodies. This is not at all congruent with the great expectations that we find in documents on the importance of women for sustainable development: "If women were in more productive and decision-making roles, we could be moving faster and more assuredly towards sustainability in the economic, social and environmental sense. Sustainable development is a political concept because it is about good governance, which will be hard to achieve until we get closer to gender parity" [6] (p. 7).

In reality, women score low in participation and leadership - which makes sense when looking at what was said above. Surveys have shown the same participation gap in Europe and in the US [46]. "Although, the participation gap among women and men in Western Europe has narrowed during the past decade, in particular with respect to voting turnout and cause-oriented political activism, men are still the dominant actors in political parties and voluntary organizations. A comprehensive study on gender and political participation in Britain [58] suggests that women often have fewer resources of time, money, and civic skills, combined with a lower psychological engagement in politics" [46] (p. 1311). However, even when the preconditions were the same, as in a sample of male/female students of the same university, gender made a difference in political engagement: Male students tended to engage in 
long-term initiatives and political committees, while female students preferred engagement for singular events or projects, mostly in the social sphere, so the results of an empirical campus study in which the author was involved [47]. These results suggest that young men consider more often a political career than young women.

The other side of the coin is that women's dedication to the household (being good mothers) gives them higher scores in pro-environmental attitudes and ethical shopping (boycotting and buycotting). According to Acik this could be their special expression of civic engagement: “... their dominance in political consumerism might be due to women's role as primary shoppers in their families, which makes them by default more likely to be ethical shoppers [59]. Alternatively, it could be that women are more attracted by decentralized and non-hierarchical forms of participation as suggested by Stromsnes [60]. Moreover, the actual act of buycotting, boycotting, or signing a petition is a relatively passive and individualized form of involvement. They are embedded in everyday activities and do not require great commitment and continuity" [46] (p. 1319). Sustainable development, however, asks for great commitment and continuity.

As we have seen, the tensions between current norms of masculinity and femininity and the norms and principles of sustainable development are of a different nature. To make it all more complex, they are intertwined: In a cross-national study Hunter, Hatch and Johnson found that when they included gross national income per capita (GNI) in their analysis of data from 22 nations, the gender differences in level of private environmental behaviors were more visible in nations at the upper end of the wealth distribution. "Yet as GNI rises, this preference for private environmental behavior becomes increasingly feminized, although the greater gender gap in wealthier contexts remains a puzzle. In a sense, the gap is a product of lower levels of engagement by men in private behaviors, suggesting that, perhaps, the biographical availability of men is different in wealthier contexts. Exploration into this intriguing possibility related to male gender role socialization is a topic of future research" [61] (pp. 691-692). Here we have a mutual reinforcement of hegemonic masculinity with the norm of the good mother, resulting in the classical separation of productive and reproductive spheres. Looking at this cleavage from a historical and economic point of view, Biesecker and Hofmeister develop their thesis that this is the reason underlying the ecological and economic crisis. As an answer they introduce the category of (Re)productivity, standing for the reconciliation of the two spheres [35].

\subsection{Gender Roles in Times of Change}

The data used in the above mentioned study were from 1993, and at the levels of concrete societal structures and individual lives/biographies, however, major changes in gender roles and gender relations have taken place in western societies over the last two decades. These might be more favorable for sustainable development and therefore they are of special relevance to sustainability communication.

\subsubsection{Working Women, New Men, Single parents, New Family Models}

In his book, "The Power of Identity" the sociologist Manuel Castells devotes one chapter to the environmental movement and another one to the threats that hegemonic masculinity is facing [49].

He never uses the term hegemonic masculinity, but he certainly talks about the same thing, e.g., in his definition of patriarchalism: "It is characterized by the institutionally enforced authority of males 
over females and their children in the family unit. For this authority to be exercised, patriarchalism must permeate the entire organization of society, from production and consumption to politics, law, and culture" [49] (p. 192). Castells' analysis of social movements, family and sexuality in the information age leads to an anticipation of "the end of patriarchalism". It is empirically based on statistical data, mainly from the US and Europe, and from UN-statistics. These data show that the model of a nuclear family has been eroding over the last decades and new models of living together and parenting have emerged: networks of support, female-headed households, single fathers, a succession of partners and patterns throughout the life-cycle, a high percentage of non-family households (single-households). Castells sees the subversion of gender coming mainly through the revolution of parenting: egalitarian parenting. "Yet, for most men, the most acceptable, stable, long-term solution is to renegotiate the heterosexual family contract. This includes domestic work sharing, economic partnership, sexual partnership, and, above everything else, full sharing of parenting" [49] (p. 293). The media, in particular commercials, reflect this trend: "Past television commercials tended to portray men as Marlboro macho or as idiots, but contemporary viewers see men cooking, feeding babies, and shopping. [62] (p. 650). The emerging "new man" is not liked by everybody [62] (pp. 650-651), sometimes not even by women, because traditional gender norms still exert impact and the devaluation by reproductive labor hits him just like women [63]. In addition, this is exactly what needs to be stressed. New definitions of what masculinity can be these days are still missing. New men find themselves in a dilemma, comparable to the working mothers' feeling of guilt, only that they feel guilty towards their employer. Sustainability communication could help to establish these badly needed new gender norms, which would go hand in hand with new concepts of and esteem for care.

\subsubsection{Effects of Environmentalism}

In the above mentioned media-analysis on meat and masculinity, Rogers finds a lot of evidence that feminism and environmentalism are seen as threats to masculinity. He refers to a biographical study of Connell in which the latter presents six life histories of men whose personal development was deeply influenced by the ethos of environmentalism on the one hand, and by the feminism of the 1970/1980s on the other. Connell calls this "a project of reform" or "remaking masculinity" [64].

The author's own findings from a biographical study go well together with Connell's theses. Biography analysis of 20 cases of pioneers in environmental communication in Germany [19] was used to shed light on the formation of environmental communication as a new occupational field. Gender analysis was expected to play a role in the interpretation of the data: Are there gender-specific ways into the field? Are traditional gender-roles re-constructed? Is there gender-equality? Do we find gender-specific differences in concepts and visions? Surprisingly, the 20 narrations did neither yield much data nor striking interpretations on gender-specific issues. This in fact was the most striking! First of all, the life histories did not reveal significant gender differences: Several women and men had risked radical changes in their careers (projects of reform), quitting jobs that were the opposite of what they did later. In their early careers the women were not less technology-affine than the men, but two of them quit research jobs in the nuclear industry which matches the results of studies on high risk perception in women [40]. Secondly, one of the essential results of the gender analysis was that the male participants, through their involvement in social movements plus working in environmental 
communication, had undergone processes of change that had eliminated attitudes and behaviors of stereotype masculine connotation. Dr. Ebert, an elderly chemist who had become head of environmental management/environmental communication of a huge chemical company, was the most conventional of all the male participants, especially regarding traditional roles in his family life. However, he was subversive insofar as he "secretely" was an active member of a group of nature conservationists that were seen to be in opposition to his company. His dream and vision was the reconciliation of nature, technology and human beings. He was looking forward to having "more time to care" as a pensioner. Neither did the women comply with female stereotypes. Social movements had had a great impact on their lifes, they were not reluctant to accept leadership within organizations or to build up their own business, all of them said that they had not experienced any kind of discrimination in their new careers ("There may be discrimination, but not against me"). Being a working mum was not a major issue. Following the principles of Grounded Theory, in which the data guide the course of the research (abductive research), it became obvious that the contribution that this study could make to theory development would be located in the sociology of social movements, with gender issues subordinate to this overarching theme.

Binding together the theses of Castells, the findings of Connell and Rogers as well as the above described own results, it can be assumed that the impact of social movements on gender roles is considerable. Sustainability communication, which is often attributed to or understood as part of an anti-mainstream movement, should use this potential and could question traditional gender norms that are in conflict with the ethics and aims of sustainable development.

\subsection{Gender-Oriented Sustainability Communication}

Three men are sitting round a table in a pub. They talk about cars, holidays and homes. One of them (stereotype of hegemonic masculinity) boasts about holidays in Namibia: "Beautiful country. Pure nature and premium hotels with super restaurants, all in one. And we did everything: safari, Atlantic ocean, sightseeing flight to the bushmen, hauling through the dunes with a jeep". Another one, who seems to be slightly "green", is laughed at for his efforts to save energy or to spend holidays by way of "soft tourism" in Romania (which took him 39 hours of driving with kids on board to get there). The list of climate sins gets longer, the longer these men's talk goes on. With the appearance of the waitress, the plot takes an unexpected turn: She presents the bill in tons of $\mathrm{CO}_{2}$ for the trips, playing golf in the desert and for the lack of energy-saving light-bulbs in the house of the "peer". When she asks who is going to pay the bill, the three look at each other, and point at two skinny Africans sitting at a table in the corner: "Oh, as usual, those two over there".

This viral spot was produced with financial support of Germany's Ministry for Economic Cooperation and Development after having won a short film competition on the theme of climate justice [65]. An interview with the authors/producers showed that the strong gender critique of the clip went back to a brainstorming of three young male film-makers in a pub. They did not have any theoretical knowledge on gender, they had never heard of hegemonic masculinity, they had no professional gender competence, they were just critically reflecting the men's world surrounding them and inside themselves. Intuitively they did the right thing, the spot seems to be well received by its target group (more than 100,000 clicks on YouTube). An empirical study (reception analysis) is still missing, though. 
Nevertheless, here the case is made for gender and diversity competence in professional environmental and sustainability communication. Analysis of media products like these helps to raise awareness for gender-oriented social marketing, the exercise can be a first step to learning about gender-sensitive or gender-oriented communication. However, to become a real gender-competent communicator, an introduction into basic gender theory and into newer anti-discriminatory concepts like gender and diversity, intersectionality and inclusion is indispensable. To assimilate all this and to be able to apply theoretical knowledge in professional practice can be a process of years (lifelong learning). A second example shows the importance of both profound gender and diversity competence and professional experience.

Every year the city of Brussels invites its citizens to the environmental fair, an exhibition of all kinds of services and initiatives around environmental protection and sustainable development in the city of Brussels. Big Posters all over metro stations and other public places announce the event. In 2012 at first sight, the marketing seemed politically correct from a gender and diversity perspective: a young family is waving happily, blonde mother, non-white father, and non-white daughter. (Brussels has a very high percentage of migrants from Africa, including many from Maghreb countries.) At second sight one sees that the mother is naked behind a lovely short dress composed of green vegetables, and here we have a problem: Her nudity might offend the feelings of the high proportion of Muslim inhabitants. Secondly, from a feminist point of view, the styling of the mother might be criticized as sexist, just like sexism in commercial advertising. Thirdly, gender analysis shows that there is a slight touch of feminization of environmental responsibility to the mother: Her dress, composed of fresh vegetables, attributes nutrition and health or the whole reproductive sphere to her figure.

These two examples are meant to illustrate how enriching and relevant it can be, if the gender dimension is integrated into the practice of sustainability communication. Target groups are not gender-neutral, and they have to be addressed in a gender-sensitive way. The second example shows that there are many pitfalls, and the broader the target group, the more we have to reflect on gender and cultural diversity implications, before we send out messages. Capacity building is needed to acquire gender and diversity-competence, higher education institutions are places where this could happen. The concept of "integrative gendering", developed at German universities, is a successful instrument of gender mainstreaming all kinds of disciplines [66], even those that have no tradition at all of teaching gender. It should also be mentioned, that the worldwide web offers excellent e-learning materials (e.g., case studies) and tools for gender analysis [38].

Together with mass media the worldwide web will probably also be the fastest means of dissemination for attractive materials as the ones described, challenging the old social norms and envisioning fair gender relations that go hand in hand with sustainability. Hurley proposes commercial film productions as means to spread such visions [67].

Education for Sustainable Development is a powerful instrument, too, to promote change regarding gender. The most important aim of ESD is to empower children as well as people of all ages. ESD professionals should encourage their target groups to emancipate themselves from overcome, unsustainable social norms, including gender norms. Again, gender and diversity competence is indispensable for this task, as well as in any other field of sustainability communication. 


\section{Conclusions}

In an interdisciplinary approach, which brings together new concepts from the fields of gender research and sustainability science with the political instrument of gender mainstreaming and public discourse on gender issues (modern mothers, new men, crisis of masculinity), a fresh look at the relationship between gender and sustainability is possible. By focusing on the abstract gender norms of masculinity and femininity and their impact on individuals and society, this perspective aims to overcome black and white attributions to a certain demographic group.

Gender norms are key for sustainable development, because they do not only influence people's worldviews and direct their behaviors, they also shape the organizational structures of societies and contribute to unjustifiable hierarchies and exploitation of resources all over the world. Traditional gender norms are in conflict with the ethics and principles of sustainable development, this was shown for both masculinity and femininity. Consequently, current gender systems have more to do with UNsustainability than with sustainability. However, gender norms are culturally constructed and they may gradually change, when social practices have changed, as Castells convincingly argues. Vice versa, practices would change under the influence of changed norms: Reconciliation of work and family, (re)productivity, respect and responsibility for others, these elements of sustainable living could go hand in hand with new gender roles and gender relations.

Communication can certainly not solve the deep-rooted conflict between the normative concept of sustainable development and masculinity and femininity as social norms. However, communication can show, explain, visualize what sustainability means and in doing so, it can question inequalities and injustice that are rooted in the gender system.

Individuals or groups of people are the agents of cultural change, and they can be inspired, irritated and moved by communication. The dynamics of web 2.0 show the enormous power of communication.

However, as we saw, there may be pitfalls. Any intervention is at risk to reproduce gender bias or discrimination or to hurt someone's feelings. Inter- and transcultural competence is an important element of gender and diversity competence today. Therefore gender and diversity mainstreaming is of advantage in all fields of environmental and sustainability communications, if we want to bring out the right messages and want them to be well received. Gender and diversity mainstreaming has to be part of training programs for environmental communicators. Moreover, it is needed in environmental and sustainability communication research, because it opens up new dimensions in the interpretation of empirical data and for project design. This, of course, applies to any field of sustainability science. The necessary tools for lifelong learning exist and are ready to be used.

\section{Acknowledgments}

Thanks to Gerd Michelsen for his confidence in my research, and to Sacha Kagan for the inspiring conversations we had, whenever we met.

\section{Conflicts of Interest}

The author declares no conflict of interest. 


\section{References and Notes}

1. Stern, P.C.; Dietz, T.; Kalof, L. Value Orientations, Gender, and Environmental Concern. Environ. Behav. 1993, 25, 322-348.

2. Dietz, T.; Kalof, L.; Stern, P.C. Gender, Values, and Environmentalism. Soc. Sci. Q. 2002, 83, 353-364.

3. Kalof, L.; Dietz, T.; Guagnano, G.; Stern, P.C. Race, Gender and Environmentalism: The Atypical Values and Beliefs of White Men. Race Gender Class 2002, 9, 112-130.

4. Hofmeister, S., Katz, C., Mölders, T., Eds. Geschlechterverhältnisse und Nachhaltigkeit. Die Kategorie Geschlecht in den Nachhaltigkeitswissenschaften, 1st ed.; Verlag Barbara Budrich: Opladen, Germany, 2013. (In German)

5. OECD. Gender and Sustainable Development. Maximising the economic, social and environmental role of women. Available online: http://www.oecd.org/social/40881538.pdf (accessed on 2 January 2014).

6. Stevens, C. Are Women the Key to Sustainable Development? Sustain. Dev. Insights 2010, 3, 1-8.

7. UNESCO. Bonn Declaration. Available online: http://www.esd-world-conference-2009.org/ fileadmin/download/ESD2009_BonnDeclaration080409.pdf (accessed on 2 January 2014).

8. Schultz, I.; Weiland, M. Frauen und Müll: Frauen als Handelnde in der kommunalen Abfallwirtschaft; Sozialökologische Arbeitspapiere; 3rd ed.; Verlag für Interkulturelle Kommunikation: Frankfurt am Main, Germany, 1990; Volume 40. (In German)

9. Schultz, I.; Stiess, E. Gender Aspects of Sustainable Consumption Strategies and Instruments. Available online: http://www.eupopp.net/docs/isoe-gender_wp1_20090426-endlv.pdf (accessed on 2 January 2014).

10. Franz-Balsen, A. Margins to Mainstream. Pan Eur. Netw. Sci. Technol. 2013, 6, 40-43.

11. UNEP and Futerra. Communicating Sustainability. How to produce effective campaigns. Available online: http://www.unep.fr/shared/publications/pdf/DTIx0679xPA-CommunicatingEN.pdf (accessed on 2 January 2014).

12. Kleinhückelkotten, S.; Wegner, E. Nachhaltigkeit kommunizieren; Ecolog: Hannover, Germany, 2008. Available online: http://www.21-kom.de/fileadmin/user_upload/PDFs/01_NHK_Social_ Marketing_Ueberblick/Nachhaltigkeit_Kommunizieren_20_08_2010_C.pdf (accessed on 2 January 2014). (In German)

13. GreenCom and Academy for Educational Development. Environmental Education \& Communication for a Sustainable World; Handbook for International Practitioners; Academy for Educational Development: Washington, DC, USA, 2000.

14. Hansen, A. Communication, media and environment: Towards reconnecting research on the production, content and social implications of environmental communication. Int. Commun. Gaz. 2011, 73, 7-25.

15. Rogers, R.A. Beasts, Burgers, and Hummers: Meat and the Crisis of Masculinity in Contemporary Television Advertisements. Environ. Commun. 2008, 2, 281-301.

16. Lee, K. Making Environmental Communications Meaningful to Female Adolescents: A Study in Hong Kong. Sci. Commun. 2008, 30, 147-176. 
17. Ling, H.; Santos, M.E. Do Women View Genetically Modified food Differently from Men? Southeast Decision Sciences Institute, University of North Carolina, Pembroke, NC, USA, 2013. Available online: http://www.sedsi.org/2013_Conference/proc/proc/P121009007.pdf (accessed on 2 January 2014).

18. Franz-Balsen, A. Unsichtbares sichtbar machen-Nachhaltigkeit und Gender in der Lehre. In Zukunft Bologna!? Dudek, A., Jansen-Schulz, B., Eds.; Peter Lang: Frankfurt am Main, Germany, 2007; pp. 265-282. (In German)

19. Franz-Balsen, A. Karrieren in der Umweltkommunikation, INFU-Diskussionsbeiträge. Institute of Environmental and Sustainability Communication, University of Lueneburg, Lueneburg, Germany, 19 March 2013. (In German)

20. Schütze, F. Biographieforschung und narratives Interview. Neue Praxis 1983, 13, $283-292$.

21. Schütze, F. Das narrative Interview in Interaktionsfeldstudien. Fernuniversität Hagen, Hagen, Germany, 1987. (In German)

22. Strauss, A. Grundlagen qualitativer Sozialforschung, 1st ed.; UTB: München, Germany, 1994. (In German)

23. Keller, E.F. Reflections on Gender and Science, 1st ed.; Yale University Press: New Haven, CT, USA, 1995.

24. Harding, S. The Science Question in Feminism, 1st ed.; Cornell University Press: Ithaca, NY, USA, 1986.

25. Haraway, D. Die Neuerfindung der Natur. Primaten, Cyborgs und Frauen, 1st ed.; Hammer, C., Stiess, E., Eds.; Campus: Frankfurt am Main, Germany, 1995. (In German)

26. Brod, H., Ed. The Making of Masculinities: The New Men's Studies, 1st ed.; Allen and Unwin: Boston, MS, USA, 1987.

27. Connell, R.W. Masculinities, 1st ed.; University of California Press: Berkeley, CA, USA, 1995.

28. Butler, J. Gender Trouble, 1st ed.; Routledge: London, UK, 1990.

29. Mies, M.; Shiva, V. Ecofeminism, 1st ed.; Fernwood Publications: Halifax, NS, Canada, 1993.

30. Plumwood, V. Feminism and the Mastery of Nature; Routledge: London, UK, 1993.

31. Mellor, M. Feminism and Ecology, 1st ed.; John Wiley \& Sons: Cambridge, UK, 1997.

32. Warren, K. Ecofeminist Philosophy: A Western Perspective on What It Is and Why It Matters; Studies in social, political and legal philosophy; Rowman \& Littlefield: Lanham, MD, USA, 2000.

33. Katz, C. Ökofeminismus. In Geschlechterverhältnisse und Nachhaltigkeit. Hofmeister, S., Katz, C., Mölders, T., Eds.; Verlag Barbara Budrich: Opladen, Germany, 2013; pp. 79-85. (In German)

34. Mellor, M. The Future of Money, 1st ed.; PlutoPress: London, UK, 2010.

35. Biesecker, A.; Hofmeister, S. Focus: (Re)productivity: Sustainable relations both between society and nature and between the genders. Ecol. Econ. 2010, 69, 1703-1711.

36. Crenshaw, K.W. Race, Reform and Retrenchment: Transformation and Legitimation in Antidiscrimination Law. Harv. Law Rev. 1988, 101, 1331-1387.

37. Weller, I. Nachhaltiger Konsum, Lebensstile und Geschlechterverhältnisse. In Geschlechterverhältnisse und Nachhaltigkeit; Hofmeister, S., Katz, C., Mölders, T., Eds.; Verlag Barbara Budrich: Opladen, Germany, 2013; pp. 286-295. (In German) 
38. Schiebinger, L. Gendered Innovations in Science, Health \& Medicine, Engineering, and Environment. Available online: http://genderedinnovations.stanford.edu/methods/gender.html (accessed on 2 January 2014).

39. Martine, G.; Villareal, M. Gender and sustainability: Re-assessing Linkages and Issues. Available online: http://www.fao.org/sd/wpdirect/wpan0020.htm (accessed on 2 January 2014).

40. Flynn, J.; Slovic, P.; Mertz, C.K. Gender, Race, and Perception of Environmental Health Risks. Risk Anal. 1994, 14, 1101-1108.

41. Finucane, M.L.; Slovic, P.; Mertz, C.K.; Flynn, J.; Satterfield, T.A. Gender, race, and perceived risk: The 'white male' effect. Health Risk Soc. 2000, 2, 159-172.

42. Palmer, C.G.S. Risk perception: Another look at the 'white male' effect. Health Risk Soc. 2003, 5, 71-83.

43. Stern, P.C.; Dietz, T. The Value Basis of Environmental Concern. J. Soc. Issues 1994, 50, 65-84.

44. Hines, J.M.; Hungerford, H.R.; Tomera, A. Analysis and Synthesis of Research on Responsible Environmental Behavior: A Meta-Analysis. J. Environ. Educ. 1987, 18, 1-8.

45. Zelezny, L.C.; Chua, P.; Aldrich, C. Elaborating on Gender Differences in Environmentalism. J. Soc. Issues 2000, 56, 443-457.

46. Acik, N. Reducing the participation gap in civic engagement: Political consumerism in Europe. Eur. Sociol. Rev. 2013, 29, 1309-1322.

47. Franz-Balsen, A.; Heinrichs, H. Managing sustainability communication on campus: Experiences from Lüneburg. Int. J. Sustain. High. Educ. 2007, 8, 431-445.

48. Lurie, S. Identifying Training Needs of Health-Care Providers Related to Treatment and Care of Transgendered Patients: A Qualitative Needs Assessment Conducted in New England. Int. J. Transgenderism 2005, 8, 93-112.

49. Castells, M. The Power of Identity, 1st ed.; Wiley-Blackwell: Chichester, UK, 1997.

50. Di Blasi, L. Der weiße Mann; Transcript Verlag: Bielefeld, Germany, 2013. (In German)

51. The Earth Charter Initiative: The Earth Charter. Available online: http://www.earthcharterinaction.org/ content/pages/Read-the-Charter.html (accessed on 2 January 2014).

52. Raether, E.; Stelzer, T. Das geschwächte Geschlecht. DIE ZEIT 2014, 2, 11-13. Available online: http://www.zeit.de/2014/02/maenner-krise-maennerbewegung (accessed on 2 January 2014). (In German)

53. Examples. Available online: http://www.luxmedia.at/klassisch-provokativ (accessed on 2 January 2014). (In German)

54. Lüchinger, R. IWC: Schluss mit Machismo. Available online: http://www.bilanz.ch/ unternehmen/iwc-schluss-mit-machismo (accessed on 2 January 2014). (In German)

55. Badinter, E. Die Mutterliebe, 1st ed.; Piper: München, Germany, 1981. (In German)

56. Daily Telegraph. Guilt of modern mothers at having too little time for children. Daily Telegraph, London, UK, 21 January 2013. Available online: http:/www.telegraph.co.uk/lifestyle/9815910/ Guilt-of-modern-mothers-at-having-too-little-time-for-children.html (accessed on 2 January 2014).

57. Degele, N. Sich schön machen, 1st ed.; VS Verlag: Wiesbaden, Germany, 2004. (In German)

58. Norris, P.; Lovenduski, J.; Campbell, R. Closing the Activism Gap: Gender and Political Participation in Britain; The Electoral Commission: London, UK, 2004. 
59. Micheletti, M. Political Virtue and Shopping: Individuals, Consumerism, and Collective Action; Palgrave: New York, NY, USA, 2003.

60. Stromsnes, K. Political consumption in Norway: Who, why-And does it have any effect? In Political Consumerism: Its Motivations, Power, and Conditions in the Nordic Countries and Elsewhere; Proceedings of the 2nd International Seminar on Political Consumption, Oslo, Norway, 26-29 August 2004; TemaNord: Copenhagen, Denmark, 2005.

61. Hunter, L.; Hatch, A.; Johnson, A. Cross-National Gender Variation in Environmental Behaviors. Soc. Sci. Q. 2004, 85, 677-694.

62. Donaldson, M. What is Hegemonic Masculinity? Theory Soc. 1993, 22, 643-657.

63. Döge, P.; Volz, R. Wollen Frauen den neuen Mann?: Traditionelle Geschlechterbilder als Blockaden von Geschlechterpolitik; Konrad-Adenauer-Stiftung: Sankt Augustin, Germany, 2002. (In German)

64. Connell, R.W. A Whole New World: Remaking Masculinity in the Context of the Environmental Movement. Gender Soc. 1990, 4, 452-478.

65. Germanwatch. The Bill. Available online: http://www.youtube.com/watch? $\mathrm{v}=\mathrm{rWfb} 0 \mathrm{VMCQHE}$ (accessed on 2 January 2014).

66. Jansen-Schulz, B. "Integrative Gendering". A Strategy for Teaching, Research and University Structures. In Bologna and Beyond. New Perspectives on Gender and Gender Studies; Grenz, S., Jähnert, G., Kortendiek, B., Eds.; Humboldt Universität: Berlin, Germany, 2008; pp. 47-62.

67. Hurley, K. Is that a future we want? An ecofeminist exploration of images of the future in contemporary film. Futures 2008, 40, 346-359.

(C) 2014 by the author; licensee MDPI, Basel, Switzerland. This article is an open access article distributed under the terms and conditions of the Creative Commons Attribution license (http://creativecommons.org/licenses/by/3.0/). 